\title{
Hurricane Driven Changes in Vegetation Structure and Ecosystem Services in Tropical Urban Yards: a Study Case in San Juan, Puerto Rico
}

\section{Sofía Olivero-Lora}

University of Puerto Rico Rio Piedras: Universidad de Puerto Rico Recinto de Rio Piedras Julissa Rojas-Sandoval

University of Conneticut

Elvia J Melendez-Ackerman ( $\nabla$ elmelend@gmail.com )

University of Puerto Rico Rio Piedras: Universidad de Puerto Rico Recinto de Rio Piedras https://orcid.org/0000-0002-0925-7916

\section{Juan Orengo-Rolon}

University of Puerto Rico Rio Piedras: Universidad de Puerto Rico Recinto de Rio Piedras

\section{Research Article}

Keywords: Caribbean, i-Tree, non-native trees, tree mortality, urban forestry, wind damage

Posted Date: October 5th, 2021

DOI: https://doi.org/10.21203/rs.3.rs-884265/v1

License: (c) (i) This work is licensed under a Creative Commons Attribution 4.0 International License. Read Full License 


\title{
Hurricane driven changes in vegetation structure and ecosystem services in tropical urban yards: a study case in San Juan, Puerto Rico
}

\author{
Sofía Olivero-Lora ${ }^{1}$, Rojas-Sandoval Julissa ${ }^{2}$, Elvia Meléndez-Ackerman ${ }^{1,3 *}$, and Juan L. \\ Orengo-Rolón ${ }^{1}$
}

${ }^{1}$ Department of Environmental Sciences, University of Puerto Rico, Rio Piedras Campus, San Juan, Puerto Rico, 00931

${ }^{2}$ Institute of the Environment, University of Connecticut, Storrs, CT 06269-4210

${ }^{3}$ Center for Applied Tropical Ecology and Conservation (CATEC), University of Puerto Rico, Rio Piedras Campus, San Juan, Puerto Rico, 00931

Julissa Rojas-Sandoval

ORCID ID: 0000-0001-6620-4741

https://orcid.org/0000-0001-6620-4741

\section{"Corresponding author}

Elvia Meléndez-Ackerman

Email: elmelend@gmail.com 


\section{ABSTRACT}

Urban forests are valuable spaces for species conservation, protection of local biodiversity and provision of ecosystem services. However, they are also vulnerable to the impact of extreme climate events like hurricanes. Understanding how urban forests are responding to hurricane disturbances is crucial to improve their design, management, and resilience. Here we analyzed pre-and post-hurricane surveys in 52 residential yards in San Juan to assess urban forests responses after Hurricanes Irma and Maria impacted Puerto Rico in 2017. We used these surveys to compare vegetation structure and composition (including species-specific mortality and damage rates) and to quantify changes in the ecosystem services provided by these yards. We found that hurricane disturbances significantly altered the structure but not the composition of yard vegetation. We detected a $27 \%$ reduction and $31 \%$ mortality of standing stems, and a significant reduction in plants health. Yard species composition was dominated by non-native species and this trend did not change with hurricane disturbance. Changes in vegetation structure translated into substantial reductions in ecosystem services. Food provision, an important service provided by a large proportion of yards before the hurricane, reported the highest reduction $(41.9 \%)$ while carbon storage was the service that changed the least $(9 \%)$. Our combined results emphasize the key role played by residential yards providing ecosystem services in tropical cities and call for further efforts to manage private and public urban forests in ways that may ensure their resilience to mitigate extreme climate events, provide multiple ecosystem services, and promote long-term urban sustainability.

Keywords: Caribbean, i-Tree, non-native trees, tree mortality, urban forestry, wind damage. 


\section{INTRODUCTION}

Globally, urban forests provide many essential ecosystem services such as carbon sequestration, reduction of air and noise pollution, mitigation of urban heat island effect and flood risk and they are also important recreational areas (Kleerekoper et al. 2012; Roy et al. 2012; Berland et al. 2017; Escobedo et al. 2019). Private green spaces (e.g., residential yards and gardens) are increasingly in the spotlight as important contributors of some of these ecosystem services because they often contain most of the urban forest resources and may provide functional connectivity across green infrastructure in cities (Gaston et al. 2005; Cook et al. 2012; Nowak and Greenfield 2018). However, studies have shown that in cities, both public and private green spaces are vulnerable to the impacts of climate change (Burley et al. 2008; Foran et al. 2015; Ordóñez and Duinker 2014; Yan and Yang 2018). Climate change models predict increases in extreme climate events worldwide, (i.e., hurricanes, tornadoes, snowstorms, heat waves, and flooding), which could disproportionately impact cities (Méndez-Lázaro et al. 2016; Yin et al. 2018; Steenberg et al. 2019). Evidence shows that urban areas are often more vulnerable to these events compared to natural areas due to the high concentration of people, infrastructure, and services (Dickson et al. 2012; McPhillips et al. 2018; Elmqvist et al. 2019). Additionally, urban forests that provide multiple ecosystem services to city residents and often mitigate problems associated to the urban condition and climate change are also expected to experience extreme weather events (Gill et al. 2007; Matthews et al. 2015; Lafortezza et al. 2017; Zölch et al. 2016; Khan and Conway 2020; Bonilla-Duarte et al., 2021). Therefore, it is critical to understand the responses of urban forests to extreme climate events for their successful planning and management in ways that ensure their resilience and sustainability in the face of climate change. 
Tropical cyclones, also known as hurricanes and typhoons, are large-scale natural disturbances with the potential to affect the structure, composition, and function of forested ecosystems in many parts of the world (Tanner et al. 2014; Xi 2015). Across the Caribbean region, hurricanes are common events, but their intensity and frequency are expected to increase in the future due to climate change (Gould et al. 2015; Kossin et al. 2020). For this region, there is a vast number of studies showing that hurricane disturbances and recovery responses can play a key role in influencing tree community composition (Lugo 2000; Ostertag et al. 2005; Canham et al. 2010; Brokaw et al. 2012). Additionally, hurricane disturbances may generate heterogeneous environments, increase resources, reduce competition, and generate growing spaces for plant recruitment (Webster et al. 2005). However, most of this information is circumscribed to natural forests limiting our understanding on how urban forests are responding to hurricane disturbances. In 2017, Puerto Rico was impacted by two intense hurricanes. Hurricane Irma (category 4) passed $90 \mathrm{~km}$ north of Puerto Rico on September 7, 2017, leaving perceivable impacts on the island's green and grey infrastructure (Uriarte et al. 2019). Two weeks later, hurricane Maria (category 4) struck Puerto Rico with sustained winds of $155 \mathrm{mph}$ and the highest rainfall intensity ever recorded on the island (Ramos-Scharrón and Arima 2019). The combined impact of these two hurricanes caused the destruction of electric infrastructure, major disruptions in telecommunications, significant damage to highways and roads, and resulted in limited access to potable water and food for several weeks (Rodríguez-Díaz 2018). Additionally, these hurricanes severely affected urban and natural forests across Puerto Rico, with an estimated immediate loss of greenness ranging from 31\% - 51\% (Van Beusekom et al. 2018) and between 20 - 40 million trees killed or severely damaged (Feng et al. 2018; Uriarte et al. 2019). 
The passage of hurricanes Irma and Maria presented an extraordinary opportunity to evaluate the extent of damage on green urban spaces and to assess how these green spaces are responding to hurricane disturbances. Here, we took advantage of an ongoing study monitoring residential yards in San Juan that was interrupted by the impacts of these two major hurricanes. Rapid posthurricane assessments were conducted in yards previously surveyed. We used these yards to perform a direct comparison of pre- and post-hurricane conditions. The specific goals of this study were to: (1) determine the impact of hurricanes Irma and Maria on vegetation structure and composition of San Juan residential yards by comparing pre-and post-hurricanes surveys, (2) evaluate and quantify hurricane-driven changes in the ecosystem services provided by these yards, and (3) assess if there were species-specific differences in terms of mortality and response to hurricane damage. The results of this study provide insight into the vulnerability and recovery potential of urban vegetation after a major hurricane. Understanding the changes in vegetation condition and ecosystem services following a major hurricane may lead to improved urban green infrastructures and management strategies.

\section{METHODS}

\section{Study Site}

The San Juan Metropolitan Area (SJMA) is the largest urban area on the island of Puerto Rico with an estimated population of 318,441 people (U.S. Census Bureau 2019). The yards surveyed in this study were single-family housing units from three neighborhoods (Puerto Nuevo, Avenida Central and La Sierra) located along the urban cover gradient of the Río Piedras Watershed (RPWS), the main watershed in the SJMA covering an area of $49 \mathrm{~km}^{2}$ (Fig. 1). These yards are part of a larger project setup established by the San Juan ULTRA Network across the RPWS 
(Melendez-Ackerman et al. 2014, 2016; Vila-Ruiz et al. 2014; Torres-Camacho et al. 2017;

Olivero-Lora et al., 2019). The RPWS is characterized by a land cover gradient that ranges from highly urbanized areas near the coast to highly forested areas around the headwater and has a mean annual temperature of $25.7^{\circ} \mathrm{C}$ and a mean annual precipitation that ranges from $1,509 \mathrm{~mm}$ in the coast to $1,755 \mathrm{~mm}$ in the upland (Lugo et al. 2011). Previous studies have shown that green spaces in residential areas within the RPWS support a biodiversity-rich flora but dominated by non-native plant species (Vila-Ruiz et al 2014; Melendez-Ackerman and RojasSandoval 2021).

\section{Pre- and post-hurricane yard surveys}

The pre-hurricane surveys included a total of 89 backyards (hereafter "yards") that were visited between June 2016 and May 2017 and inventoried following the i-Tree Eco protocol (Nowak et al. 2018). Within each yard, all woody species (trees and shrubs) as well as palms and large herbs (e.g., plantains and bananas) with diameter at breast height $(\mathrm{DBH}) \geq 2.5 \mathrm{~cm}$ were surveyed and used to gather the following variables: species, $\mathrm{DBH}$, height, crown length, percent crown missing, percent dieback, and crown light exposure. Each species was classified as native or nonnative in Puerto Rico following Axelrod (2001) and the presence (or not) of food provision value and ornamental value was evaluated following USDA-ARS-GRIN (2019). Finally, information on wood density for each species was also collected from the literature (Brown 1997; Chave et al. 2009; Carsan et al. 2012) and used to evaluate a potential association between wood density and the likelihood of surviving hurricane damage. 
In October 2017, one month after hurricane Maria, yards were revisited. Due to different logistic constraints (i.e., gasoline cutoffs, lack of transportation, infrastructure, resources, and personnel) we were able to perform post-hurricane surveys in only 69 out of the original 89 yards. To assess the tree "health condition" and the "damage" caused by the hurricanes, the variable crown condition (defined as 1 - \% dieback) was recorded for each individual plant. The frequency of broken or uprooted trees as well as information about any indication of "recovery" (e.g., presence of new leaves and branches resprouting from trunks or stumps) were also documented for each individual plant. Out of the 69 revisited yards, 15 did not have plants fulfilling the $\mathrm{DBH}$ sampling requirement $(\mathrm{DBH} \geq 2.5 \mathrm{~cm})$, therefore they were not included in post-hurricane surveys lowering the sample size to 52 yards. For all the surveyed yards, we estimated the total area $\left(\mathrm{m}^{2}\right)$ from using Google Earth Pro v.7.3. The 52 yards with pre- and posthurricane surveys covered an area of 7,129 $\mathrm{m}^{2}$. All the variables recorded for pre- and posthurricane surveys, their definitions and sources are provided in Table 1.

\section{i-Tree models}

The i-Tree Eco v.6 modeling tool (https://www.itreetools.org/) was used to generate pre- and posthurricane estimates for all yards pooled and for each yard separately for the following ecosystem services: (1) Carbon storage ( $\mathrm{kg}$ ); (2) Gross carbon sequestration ( $\mathrm{kg} / \mathrm{yr})$; (3) Avoided runoff $\left(\mathrm{m}^{2} / \mathrm{yr}\right)$; (4) Oxygen produced ( $\left.\mathrm{kg} / \mathrm{yr}\right)$; (5) Pollution removed (g/yr); and (6) Cooling energy savings (Kwh/yr). The i-Tree Eco protocol has been extensively used to assess the structure and related ecosystem services and disservices of urban forests. To estimate ecosystem services provided for the surveyed yards, air quality data [carbon monoxide $\mathrm{CO}(\mathrm{ppm} / \mathrm{hr})$, nitrogen dioxide $\mathrm{NO}_{2}(\mathrm{ppm} / \mathrm{hr})$, ozone $\mathrm{O}_{3}(\mathrm{ppm} / \mathrm{hr})$, sulfur dioxide $\mathrm{SO}_{3}(\mathrm{ppm} / \mathrm{hr})$, breathable suspended 
particulate matter PM10 $\left(\boldsymbol{\mu g} / \mathrm{m}^{3}\right)$, and fine particulate matter PM2.5 $\left.(\boldsymbol{\mu g} / \mathrm{m} 3)\right]$, as well as temperature $\left({ }^{\circ} \mathrm{C}\right)$, rainfall $(\mathrm{cm} / \mathrm{hr})$ and wind velocity $(\mathrm{m} / \mathrm{s})$ were obtained from the National Weather Service Station located in Luis Muñoz Marín International Airport (LMMAUSAF:785263). Values for electricity were modified to 20 cents (US\$) per kilowatt-hour based on estimates for Puerto Rico in 2017 (U.S. Energy Information Administration 2018) and heating costs to zero due to the lack of frost days on the island. Default values were used for the price of carbon (US\$188/metric ton) and avoided runoff (US\$2.36/ $\left.\mathrm{m}^{3}\right)$.

\section{Data analysis}

Descriptive statistics, contingency analyses, and sign tests were used to evaluate changes in vegetation structure and composition between pre- and post-hurricane surveys. We used $\chi^{2}$ tests to compare the pre- and post-hurricane distribution frequency of individuals across the five DBH classes and to evaluate differences in the distribution frequency considering two condition categories: "dead" or "alive". For these analyses, the expected frequencies were the frequencies collected in the pre-hurricane surveys and standardized residuals ( $z$-scores) were considered for post-hoc analyses of cell comparisons (Field 2013; Agresti 2019). A Wilcoxon signed-rank test was used to determine hurricane-driven changes in crown condition. This analysis was performed using the ordinal position assigned to each of the seven categories evaluated for the "crown condition" variable (Table 1). To evaluate potential changes in the ecosystem services provided by yards, we used the pre- and post-hurricane surveys to estimate the percent loss of each ecosystem service for each yard and pooled yards as:

$$
\% \text { loss }=-100 * \frac{(\text { post }- \text { pre })}{\text { pre }}
$$




\section{Species-specific difference in hurricane damage and contribution to ecosystem services}

To evaluate species-specific differences in terms of mortality and response to hurricane damage, we first evaluated the relative contribution of each species to the total amount of each ecosystem service (species ES contribution / total ES contribution $\times 100$ ). Then, for each species we created an ecosystem service index (ESI) by adding its relative contribution to each of the eight ecosystem services evaluated. For food and ornamental services, values were calculated as the relative frequency of stems with those services out of the total number of stems of all species combined. For all other ecosystem services, values were extracted from i-Tree estimates. For each species, the ESI index then reflects its relative contribution to multiple ecosystem services. To estimate hurricane-driven changes on ecosystems service at the species level, we calculated the percent loss of these services for each species using the same method that was previously used to estimate losses at the yard level but using values for each species.

For each species, we also estimated the mortality rate as the ratio between the number of dead individuals in post-hurricane surveys and number of individuals alive in the pre-hurricane surveys (Table S1 and S2). Binomial logistic regression models were used to evaluate if the probability of dying (mortality) for each species could be influenced by specific structural variables and pre-hurricane crown condition. For these analyses, only continuous structural variables (i.e., plant height, wood density, and DBH) and species with 10 or more individuals/survey were included. Due to low frequencies in crosstabulation, the original seven categories evaluated for crown condition were reduced to just three categories: bad ( $\geq 26 \%$ dieback), fair ( $11 \%$ to $25 \%$ dieback) or good ( $\leq 10 \%$ dieback). We started by creating a "full model" including all variables and then new models were created by simplifying the full model. 
The best-fit models were selected using the Akaike Information Criteria (AIC) (Burnham and Anderson 2002). All analysis was performed using SPSS v.25 (IBM Corp. Released, 2017).

\section{RESULTS}

\section{Hurricane-driven changes in vegetation structure and composition}

Pre-hurricane surveys accounted a total of 491 individuals distributed across 95 species (16 natives and 79 non-natives). A clear dominance of non-native species was detected at the individual level (91.6\% non-native species and 8.4\% native species). Pre-hurricane surveys also showed that yards were dominated $(82.3 \%$ of all vegetation) by small-stem plants with $\mathrm{DBH} \leq$ $15.2 \mathrm{~cm}$ and the species Musa paradisiaca, Hibiscus rosa-sinensis, Ptychosperma macarthurii Ficus benjamina, and Musa acuminata were at the top of the most abundant (Fig. 2; Table S1). The total canopy cover estimated was $4,760 \mathrm{~m}^{2}(66.8 \%$ of the total area surveyed).

The post-hurricane surveys showed that yards lost 152 individuals (27.7\%) and 9 species $(9.5 \%)$ representing an overall mortality of $31 \%$. The proportion of native and non-native species in post-hurricane surveys changed very little (89.3\% non-native species and $10.7 \%$ native species). However, when we analyzed the life-form of the surviving species, we found a significant reduction in the number of individuals classified as large herbs, decreasing from 115 individuals (23.4\%) in the pre-hurricane survey to just 45 individual (12.7\%) after the hurricane. This reduction was mostly due to high mortality rates detected for two herb species, Musa paradisiaca $($ mortality $=65.9 \%)$ and Musa acuminata $($ mortality $=55.6 \%)$, the species with the highest mortality rates in our yards (Table S1). Nevertheless, after the hurricane, the species Musa paradisiaca was still at the top of the most abundant followed by Hibiscus rosa-sinensis, Ficus benjamina, Ptychosperma macarthurii, and Dypsis lutescens (Fig. 2; Table S1). At the 
yard level, we also detected a significant reduction in the median value for most of the variables associated to vegetation structure (Table 2). Some of the structural variables that registered significant losses were total canopy cover (20.5\% loss), leaf area (19.6\% loss), and leaf biomass (22.2\% loss). No significant differences were observed for DBH, plant height, and basal area (Table 2). Wood density values between species ranged from 0.36 to $0.70 \mathrm{~g} / \mathrm{cm}^{3}$, but no association was detected between wood density and tree survival $(p>0.05)$.

When we compared the distribution frequency of individuals across the DBH size-classes for pre-and post-hurricane surveys, no significant differences were detected $\left(\chi^{2}=5.95, \mathrm{df}=4, \mathrm{p}\right.$ $=0.203$ ). However, significant differences were observed for the frequency distribution of trees that were "dead" or "alive" $\left(\chi^{2}=21.86, \mathrm{df}=4, \mathrm{p}<0.001\right.$, Fig. 3$)$. We found that the proportion of "dead" individuals was significantly higher in the two smallest DBH size-classes $(<15.2 \mathrm{~cm} ; z$ $=-2.7, \mathrm{p}<0.01)$ relative to larger ones $(\mathrm{DBH}>15.3 \mathrm{~cm} ; z=3.5, \mathrm{p}<0.001 ;$ Fig. 3$)$. The crown condition of surveyed plants displayed a dramatic decline following the hurricanes $\left(\chi^{2}=7028.6\right.$, $\mathrm{df}=6, \mathrm{p}<0.001 ;$ Fig. 4). The number of individuals in excellent, good, and fair condition decreased by $92 \%, 75 \%$ and $70 \%$ respectively, while the number of individuals in poor and critical condition increased by a factor of three and 10 respectively (Wilcoxon signed-ranked test $Z=-17.3, \mathrm{p}<0.001$; Fig. 4). One month after the hurricane, $88.7 \%$ of the remaining standing plants within the yards were showing some of form of recovery including the production of new leaves and new branches resprouting from stems and trunks.

\section{Hurricane-driven changes in ecosystem services}

When we analyzed pre- and post-hurricanes surveys pooling data from all yards, we found reductions for all the ecosystem services evaluated but these reductions were not necessarily 
homogeneous across services. The percent loss ranged from $9.2 \%$ to $41.9 \%$ with the largest and smallest losses observed for food production and carbon storage respectively (Table 3). A similar trend was detected when individual yard data were considered (Fig. 5). For those services evaluated with i-Tree-Eco, the largest losses were detected in avoided runoff and pollution removal in both the pooled (Table 3) and the individual yard data analyses (Fig. 5).

\section{Species-specific differences in hurricane damage and contribution to ecosystem services}

Before the hurricane, the species with the highest ESI index and therefore with the highest contribution to different ecosystem services was Mangifera indica, followed by Musa paradisiaca, Ptychosperma macarthurii and Caesalpinia ferrea (Fig. 6a). Eleven species included in the ESI top-20 were species often planted as "food species" (Musa spp., Citrus spp., Psidium guajava, Mangifera indica, Annona muricata, Persea americana, Artocarpus altilis, and Cocos nucifera). We also found that seven species in this top-20 ESI list (Caesalpinia ferrea, Artocarpus altilis, Cocus nucifera, Pterocarpus indicus, Schefflera arboricola, Malpighia emarginata, and Roystonea regia) are species that beside their contribution to the different ecosystem services, were found in low frequency ( $<5$ individuals) across the yards (Fig. 6; Table $\mathrm{S} 1$ and S2). The binomial logistic regression testing species mortality as a function of structural variables and previous crown condition yielded a best-fit model that included only one variable: DBH (Likelihood ratio $\chi^{2}=25.492, p=0.20$; Table 4). This model classified $82 \%$ of cases correctly and explained $20.2 \%$ of variation. Based on this model, the likelihood of dying decreases 0.9 times with each increase in stem diameter units.

At the species level, important losses for all ecosystem services evaluated were observed, with some species experiencing ESI value reductions of more than 50\% (Fig. 6b). For example, 
Musa acuminata and M. paradisiaca, two of the species with the highest ESI indexes and among the most common across yards in pre-hurricane surveys, were the species registering the largest losses (Fig. 6b). The tree Pterocarpus indicus and the palm Roystonea regia were the species showing the largest losses in ornamental value. On the other hand, Mangifera indica, the species with the highest ESI index and highest contribution to different ecosystem services before the hurricane, experienced a $25 \%$ reduction on the food production's ESI value but just minimal losses $(<5 \%)$ for the other ecosystem services (Fig. 6a, b).

\section{DISCUSSION}

\section{Hurricane-driven changes in vegetation structure and composition}

This study evaluated hurricane-driven changes in vegetation structure, composition, and ecosystem services in residential yards in San Juan, an urban area where private yards occupy a significant fraction of the total green infrastructure available (Lugo et al. 2011; Ramos-González 2014). Our results showed that Hurricanes Irma and Maria produced high overall mortality $(\sim 31 \%)$ in these residential yards, with mortality values twice as high than the average reported for forested areas on the island after the same hurricanes (average $=15.40 \%$; Uriarte et al., 2019). One potential explanation for this elevated overall mortality in our yards could be related to the inclusion of large herbs in our vegetation surveys, specifically the inclusion of Musa spp. These species registered the highest mortality rates $(>55 \%)$ in post-hurricane surveys, and due to their life-form, they are highly susceptible to wind damage (Paull and Duerte 2011).

Nevertheless, when we recalculated the overall mortality excluding Musa spp., the resulted rates remained considerably high $(\sim 21 \%)$. Another potential explanation could be related to the dominance of non-native species ( $>90 \%)$ registered in these yards. Our findings agree with 
previous studies showing that San Juan residential yards are composed of more non-native species and fewer native species (Meléndez-Ackerman et al. 2014; Vila-Ruiz et al. 2014; Meléndez-Ackerman and Rojas-Sandoval 2021). Additionally, it has been suggested that native species cope better with hurricane disturbances and have higher survival rates than non-native species (Brokaw et al. 2012; Duryea et al. 2007; Duryea and Kampf 2014). These differences in the responses of native and non-native species to hurricane damage could explain (at least in part) the high mortality rates observed in our yards that are dominated by non-natives and the relative lower mortality rates reported for natural forests, which are areas often dominated by native species or with lower proportion of non-native species than our yards (Ackerman et al. 2017; Zimmerman et al. 2021). However, more studies evaluating hurricane responses of native and non-native species in urban and natural forests are needed to understand the extent of these results.

Based on previous studies, we expected to find relationships between plant structural variables and tree damage/mortality related to hurricane disturbance. For example, previous studies evaluating hurricane damage have suggested a positive relationship between plant height and mortality, and lower mortality rates have been detected for species with higher wood densities (Zimmerman et al. 1994; Francis 2000; Uriarte et al. 2019). Similarly, crown condition has been used as a good predictor of tree mortality in urban forests (Koeser et al., 2013; Steenberg et al., 2019, Table 6) and as an indicator of vulnerability to hurricane damage in natural forests (Ostertag et al. 2005; Tanner et al. 2014). However, we did not detect any of these relationships and our results only show a negative correlation between DBH and mortality (see below). This lack of association could be related to the small sample size (only 52 yards with pre- and post-hurricane surveys) and/or to the low number of individuals registered for most 
species in the surveyed yards $(>88 \%$ species have less than 10 individuals in the pre-hurricane survey). Another possible explanation could be related to differences in the methods used to collect the data. For example, there are clear differences between studies in the classification used to evaluate canopy health and crown condition as well as the time intervals after the hurricane when data were collected (varying from days, weeks, and months; Ostertag et al. 2005; Tanner et al. 2014; McLaren et al. 2019). In this regard, evidence indicates that hurricane damage can result in "delayed" mortality, that can occur several months or even years after the hurricane event (Lugo 2008; Uriarte et al. 2019), including an additional variation factor that should be consider when comparing studies. Our mortality estimates took place immediately after the hurricane and may not reflect long-term mortality. Our results also showed that tree condition based on dieback evaluations worsen for most trees following the hurricane. Therefore, long-term tree mortality in residential yards is still possible which may resent further losses in the ecosystem services provided.

We found that for plants growing within yards in San Juan, the probability of dying decreased with increases in stem size (DBH). This result appears somewhat contradictory when compared to findings from a previous study suggesting that for some species mortality increases with stem size (Zimmerman et al. 1994). However, it is consistent with results obtained from urban forests where high mortality rates were observed in small-stem classes (Steenberg et al. 2017, 2019). This apparent incongruency could be explained by the forests type evaluated: urban vs. natural. Evidence has shown that natural and urban forests often differ in their structural variables, composition, and management regimes (Zhao et al. 2010; Timilsina et al. 2014). Therefore, two plausible alternatives could be that hurricanes are having different impacts in urban and natural forests, or that in urban spaces, plant species may be responding differently to 
hurricane damage compared to plants in natural forests. Nevertheless, as we mentioned before, more studies assessing how plant species are responding to hurricane disturbances in urban and natural forests are needed to evaluate these hypotheses.

\section{Hurricane-driven changes in ecosystem services}

When we analyzed the impact of hurricane disturbances on ecosystem services, we found that the damage caused in leaves, branches, and canopy structure (i.e., changes in canopy cover, leaf area and leaf biomass) translated into considerable reductions in the supply of ecosystem services. Among all the ecosystem services evaluated, food production was the most affected, losing up to $40 \%$ of its pre-hurricane capacity. This value is critical, even more when we consider that Puerto Rico currently imports over $80 \%$ of its food supply (Gould et al. 2015). This dependency on food imports makes Puerto Rican food security vulnerable to fluctuations in global food prices, transportation fuel prices, and the effects of climate change all of which may influence and interrupt supply chains (Gould et al. 2017; Benach et al. 2019; National Academies of Sciences, Engineering, and Medicine 2020). The other two ecosystem services vastly affected by the hurricanes were avoided runoff (also known as rainfall infiltration) and pollution removal. Decreases in air quality and rainfall infiltration are also problematic in San Juan, since a large part of the city is in a nonattainment area for sulfur dioxide $\mathrm{SO}_{2}$ with high air pollution concentrations due to local emissions from power plants and generators and high vehicle and ship traffic (Subramanian et al. 2018). Additionally, some of the largest residential areas in San Juan (e.g., the RPWS) are in flood hazard areas and are highly vulnerable to extreme heat events (Muñoz-Erickson et al., 2014; Méndez-Lázaro et al., 2018). Overall, this indicates that San Juan is already a vulnerable urban system and by losing ecosystem services this city is becoming even 
more vulnerable to hurricane disturbances. These results also warn about the need to improve the resilience capacity of this fragile urban system. Previous studies have suggested that urban forests in Puerto Rico are very dynamic and that high humidity and warm conditions prevailing all year long facilitate rapid growth and recovery of urban vegetation after disturbances (Lugo et al. 2011; Tucker Lima et al. 2013; Muñoz-Erickson 2014). However, residential yards are privately owned and subject to human selective pressures and management that may hinder the recovery of ecosystem services. A prior study shows that yard owners in San Juan have prioritized food production, air purification, ornamental value, and temperature reduction above other services (Olivero-Lora et al. 2019). Therefore, decision makers and managers should use these preferences as a guide to develop management plans for these areas. Sustainable and resilient yards providing multiple ecosystem services should be a priority in this city even more in the face of ongoing climate change.

\section{Species-specific difference in hurricane damage and contribution to ecosystem services}

Our results showed that plant species growing in San Juan yards differed in their contribution but also in their losses to ecosystems services. For example, Musa species led the contribution to food production service and are important food plants cultivated across the yards, but they are highly vulnerable to hurricane damage and among the species contributing the most to the loss of ecosystem services. On the other hand, Mangifera indica was the species with the highest individual contribution to different ecosystem services before the hurricane and just minimal losses in its contribution to most ecosystem services were detected after the hurricane. These species-specific differences call for further examination in the selection and management of plant 
species promoted for ecosystem services including additional evaluation of their susceptibility/resilience to climate change and hurricanes.

One interesting result of this study is that many species that are popular and preferred by yard owners for their fruits (e.g., Annona muricata, Artocarpus altilis, Psidium guajava) and as ornamentals (e.g., Ptychosperma macarthurii, Hibiscus rosa-sinensis, Pterocardus indicus), in addition to had been among those contributing significantly to the loss of ecosystem services, are non-native species that have been listed as invasive and/or potentially invasive in Puerto Rico and other Caribbean islands (Rojas-Sandoval and Acevedo 2015; Rojas-Sandoval et al. 2017; Melendez-Ackerman and Rojas-Sandoval 2021). Because it has been shown that cultivation for ornamental and food purposes are among the main pathways for the introduction of invasive plants on Caribbean islands (Rojas-Sandoval and Ackerman 2021), the continued cultivation of these non-native species entails the risk of becoming an environmental problem if they escaped cultivation. Therefore, additional studies looking for native options to replace these popular nonnative ornamentals and food plants that at the same time can provide effective ecosystem services in urban areas are urgent and should be encourage. One suitable example of a native species that could be promoted is the endemic palm Roystonea borinquena. This is a native palm, with great ornamental potential, that can also provide an important food source to native birds and bees and our results for this species showed very low damage and high survival rates ( $0 \%$ mortality) after hurricanes Irma and Maria (Francis and Lowe 2000; this study). At the same time, we recognize that applying ecosystem services approaches to support biodiversity may bring challenges when social and ecological trade-offs and other complexities are considered (Ingram et al. 2012; Birkhofer et al. 2015; Austin 2016). 
Urban Ecosystems

\section{CONCLUSION}

Our data for the surveyed yards in San Juan showed that hurricane disturbances significantly altered vegetation structure and those changes translated into substantial reductions in the ecosystem services provided by these yards, highlighting the vulnerability of this urban system to major storms. Overall, our results emphasize the key role that residential yards can play providing ecosystem services in tropical cities and call for further efforts to evaluate more extensively private areas that may contribute to support green infrastructure, mitigate extreme climate events, provide multiple ecosystem services, and promote long-term urban sustainability. From our perspective, this could be achieved through regulation, education, experimental plantings with native plant species, and promotion of best management practices, with the goals of improving ecosystem services, increasing connectivity, conservation of native species, educational value, and open space for the community. Further studies evaluating the long-term dynamics of ecosystem services provided by public and private green spaces in this city are recommended. For cities like San Juan, located in hurricane-prone areas, increasing our understanding of how gray and green infrastructures are responding to extreme climate events like hurricanes can inform management decisions and restoration efforts and it is very relevant within the context of the ongoing climate change.

\section{ACKNOWLEDGEMENTS}

Funds for this study were obtained via science crowdfunding campaign (DOI: 10.18258/10080) and we would like to thank our backers for their support. This study was also supported by the Center for Applied Tropical Ecology and Conservation (CATEC) and the Institute for Tropical Ecosystem Studies (ITES). S.O-L was supported by the Office of the Dean of Graduate Studies 
and Research (UPR-DEGI). We also thank J. Orengo, W. Rivera, L. Díaz-Perez, J. García, A. López and C. Aviles and many volunteers and students from the Tropical Plant Ecology and Evolution Lab at the University of Puerto Rico for their help with laboratory and fieldwork.

\section{DECLARATIONS}

Funding: Funds for this study were obtained via science crowdfunding campaign (DOI: 10.18258/10080), the NSF-ULTRA Grant No. 0948507; USDA Forest Service International Institute of Tropical Forestry; NSF-CREST (HRD 0206200); NSF-IGERT (Grant No. 0801577); NSF-GK-12 (Grant No. 0841338) to the Department of Environmental Sciences of the University of Puerto Rico, Rio Piedras (UPRRP).

Conflicts of interest/Competing interests: There are no conflicts of interest and/or competing interests.

Availability of data and material: All the data used in this study are available upon request in the San Juan ULTRA Project website http://sanjuanultra.org/

Code availability: Not applicable.

Authors' contributions: S.O-L and E.M-A conceived and designed the study, S.O-L and J.O performed the fieldwork and compiled the dataset. S.O-L and J.R-S analyzed the data. S.O-L and J.R-S led the manuscript writing with major inputs from E.M-A. All authors provided final approval for publication. 


\section{REFERENCES}

Ackerman JD, Tremblay RL, Rojas-Sandoval J, Hernández-Figueroa E (2017) Biotic resistance in the tropics: patterns of seed plant invasions within an island. Biological Invasions 19(1):31528.

Agresti A (2019) Categorical Data Analysis., Third edit. ed. John Wiley \& Sons, Hoboken, NJ, USA.

Austin Z, McVittie A, McCracken D, Moxey A, Moran D, White PC (2016) The co-benefits of biodiversity conservation programmes on wider ecosystem services. Ecosystem services 20:3743. https://doi.org/10.1016/j.ecoser.2016.06.002

Axelrod FS (2011) A systematic vademecum to the vascular plants of Puerto Rico. BRIT Press.

Benach J, Díaz MR, Muñoz NJ, Martínez-Herrera E, Pericàs JM (2019) What the Puerto Rican hurricanes make visible: Chronicle of a public health disaster foretold. Soc. Sci. Med. 238. https://doi.org/10.1016/j.socscimed.2019.112367

Birkhofer K, Diehl E, Andersson J, Ekroos J, Früh-Müller A, Machnikowski F, Mader VL, Nilsson L, Sasaki K, Rundlöf M, Wolters V (2015) Ecosystem services-current challenges and opportunities for ecological research. Frontiers in Ecology and Evolution 12(2):87. https://doi.org/10.3389/fevo.2014.00087

Bonilla-Duarte S, Gómez-Valenzuela V, Vargas-de la Mora AL, García-García A (2021) Urban Forest Sustainability in Residential Areas in the City of Santo Domingo. Forests 12(7):884.

Brokaw N, Crowl T, Lugo A, McDowell W, Scatena F, Waide R, Willig M (2012) A Caribbean forest tapestry. The Multidimensional Nature of Disturbance and Response. Oxford University Press, New York, USA.

Brown S (1997) Estimating biomass and biomass change of tropical forests: a primer. Food and Agriculture Organization of the United Nations.

Burley S, Robinson SL, Lundholm JT (2008) Post-hurricane vegetation recovery in an urban forest. Landsc. Urban Plan. 85: 111-122. https://doi.org/10.1016/j.landurbplan.2007.10.003

Burnham KP, Anderson DR (2002) Model Selection and Multimodel Inference: a Practical Information-theoretic Approach, 2nd Edn. New York, NY: Springer-Verlag.

Canham CD, Thompson J, Zimmerman JK, Uriarte M (2010) Variation in susceptibility to hurricane damage as a function of storm intensity in Puerto Rican tree species. Biotropica 42: 87-94. https://doi.org/10.1111/j.1744-7429.2009.00545.x

Carsan S, Orwa C, Harwood C, Kindt R, Stroebel A, Neufeldt H, Jamnadass R (2012) African Wood Density Database. Nairobi. 
Chave J, Coomes D, Jansen S, Lewis SL, Swenson NG, Zanne AE (2009) Towards a worldwide wood economics spectrum. Ecol. Lett. 12:151-366. https://doi.org/10.1111/j.14610248.2009.01285.x

Cook EM, Hall SJ, Larson KL (2012) Residential landscapes as social-ecological systems: A synthesis of multi-scalar interactions between people and their home environment. Urban Ecosyst.15: 19-52. https://doi.org/10.1007/s11252-011-0197-0

Dickson E, Baker J, Hoornweg D, Tiwari A (2012) Urban risk assessments : understanding disaster and climate risk in cities. Work Bank Publication. Washington DC.

Duryea ML, Kampf E, Littell RC (2007) Hurricanes and the urban forest: I. Effects on southeastern United States coastal plain tree species. Arboric. Urban For. 33:83-97.

Duryea M, Kampf E (2014) Selecting tropical and subtropical tree species for wind resistance. Urban For. Hurric. Recover. Progr. 1-13.

Elmqvist T, Andersson E, Frantzeskaki N, McPhearson T, Olsson P, Gaffney O, Takeuchi K, Folke C (2019) Sustainability and resilience for transformation in the urban century. Nature 2(4):267-73.

Escobedo FJ, Giannico V, Jim CY, Sanesi G, Lafortezza R (2019) Urban forests, ecosystem services, green infrastructure and nature-based solutions: Nexus or evolving metaphors?. Urban Forestry \& Urban Greening 37:3-12.

Feng Y, Negron-Juarez R, Patricola C, Collins W, Uriarte M, Hall J, Clinton N, Chambers J (2018) Rapid remote sensing assessment of impacts from Hurricane Maria on forests of Puerto Rico. PeerJ Prepr. 6:e26597v1:1-13.

Field A (2013) Discovering statistics using IBM SPSS statistics, Fourth edi. ed. SAGE Publications Ltd, London, UK.

Foran CM, Baker KM, Narcisi MJ, Linkov I (2015) Susceptibility assessment of urban tree species in Cambridge, MA, from future climatic extremes. Environ. Syst. Decis. 35: 389-400. https://doi.org/10.1007/s10669-015-9563-4

Francis JK (2000) Comparison of hurricane damage to several species of urban trees in San Juan, Puerto Rico. J. Arboric. 26:189-197.

Francis JK, Lowe CA (2000) Silvics of Native and Exotic Trees of Puerto Rico and the Caribbean Islands, General technical report IITF-15 : Bioecología de arboles nativos y exóticos de Puerto Rico y las Indias Occidentales. Río Piedras, Puerto Rico.

Gaston KJ, Warren PH, Thompson K, Smith RM (2005) Urban domestic gardens (IV): The 
extent of the resource and its associated features. Biodivers. Conserv. 14: 3327-3349. https://doi.org/10.1007/s10531-004-9513-9

Gill S, Handley J, Ennos A, Pauleit S (2007) Adapting Cities for Climate Change: The Role of the Green Infrastructure. Built Environ. 33:115-133. https://doi.org/10.2148/benv.33.1.115

Gould WA, Fain SJ, Pares IK, McGinley K, Perry A, Steele RF (2015) Caribbean Regional Climate Sub Hub Assessment of Climate Change Vulnerability and Adaptation and Mitigation Strategies. USDA Forest Service, International Institute of Tropical Forestry, Rio Piedras, PR.

Gould WA, Wadsworth FH, Quiñones M, Fain SJ, Álvarez-Berríos NL (2017) Land use, conservation, forestry, and agriculture in Puerto Rico. Forests. 8(7):242.

Ingram JC, Redford KH, Watson JE (2012) Applying ecosystem services approaches for biodiversity conservation: benefits and challenges. SAPI EN.S. Surveys and Perspectives Integrating Environment and Society. https://journals.openedition.org/sapiens/1459

Khan T, Conway TM (2020) Vulnerability of common urban forest species to projected climate change and practitioners perceptions and responses. Environmental Management 65(4):534-47.

Kleerekoper L, Van Esch M, Salcedo TB (2012) How to make a city climate-proof, addressing the urban heat island effect. Resources, Conserv Recycling 64:30-8.

Kossin, JP, Knapp KR, Olander TL, Velden C (2020) Global increase in major tropical cyclone exceedance probability over the past four decades. PNAS 117(22):11975-11980.

https://doi.org/10.1073/pnas.1920849117

Lafortezza R, Pauleit S, Hansen R, Sanesi G, Davies C (2017) Strategic green infrastructure planning and urban forestry. In: Ferrini F, Konijnendijk van den Bosch CC, Fini A (eds), Routledge Handbook of Urban Forestry. Routledge, London, UK; New York, USA, pp. 179193. https://doi.org/10.4324/9781315627106

Lugo AE (2000) Effects and outcomes of Caribbean hurricanes in a climate change scenario. Sci. Total Environ. 262: 243-251. https://doi.org/10.1016/S0048-9697(00)00526-X

Lugo AE (2008) Visible and invisible effects of hurricanes on forest ecosystems: An international review. Austral Ecol. 33:368-398. https://doi.org/10.1111/j.14429993.2008.01894.x

Lugo AE, González OMR, Pedraza CR, Ramos O, Rodriguez C (2011) The Río Piedras Watershed and its Surrounding Environment. Río Piedras Watershed its Surround. Environ. FS980 :46. https://doi.org/FS-980

Matthews T, Lo AY, Byrne JA (2015) Reconceptualizing green infrastructure for climate change adaptation: Barriers to adoption and drivers for uptake by spatial planners. Landsc. Urban Plan. 138:155-163. https://doi.org/10.1016/j.landurbplan.2015.02.010 
McLaren K, Luke D, Tanner E, Bellingham PJ, Healey JR (2019) Reconstructing the effects of hurricanes over 155 years on the structure and diversity of trees in two tropical montane rainforests in Jamaica. Agric. For. Meteorol. 276-277:1-22.

https://doi.org/10.1016/j.agrformet.2019.107621

McPhillips LE, Chang H, Chester MV, Depietri Y, Friedman E, Grimm NB, Kominoski JS, McPhearson T, Méndez-Lázaro P, Rosi EJ, Shafiei Shiva J (2018) Defining Extreme Events: A Cross-Disciplinary Review. Earth's Futur. 6: 441-455. https://doi.org/10.1002/2017EF000686

Meléndez-Ackerman EJ, Santiago-Bartolomei R, Vila-Ruiz CP, Santiago LE, García-Montiel D, Verdejo-Ortiz JC, Manrique-Hernández H, Hernández-Calo E (2014) Socioeconomic drivers of yard sustainable practices in a tropical city. Ecol. Soc. 19:1-20. https://doi.org/10.5751/ES06563-190320

Meléndez-Ackerman EJ, Nytch CJ, Santiago-Acevedo LE, Verdejo-Ortiz JC, SantiagoBartolomei R, Ramos-Santiago LE, Muñoz-Erickson TA (2016) Synthesis of household yard area dynamics in the city of San Juan using multi-scalar social-ecological perspectives. Sustainability 8(5):481.

Meléndez-Ackerman EJ, Rojas-Sandoval J (2021) Profiling native and introduced perennial garden plants in Puerto Rican urban residential yards, Journal of Urban Ecology 7: 1-12 https://doi.org/10.1093/jue/juaa037

Méndez-Lázaro PA, Pérez-Cardona CM, Rodríguez E, Martínez O, Taboas M, Bocanegra A, Méndez-Tejeda R (2016) Climate change, heat, and mortality in the tropical urban area of San Juan, Puerto Rico. Int. J. Biometeorol. 62, 699-707. https://doi.org/10.1007/s00484-016-1291-z

Méndez-Lázaro P, Muller-Karger FE, Otis D, McCarthy MJ, Rodríguez E (2018) A heat vulnerability index to improve urban public health management in San Juan, Puerto Rico. Int. J. Biometeorol. 62:709-722. https://doi.org/10.1007/s00484-017-1319-z

Muñoz-Erickson TA (2014) Multiple pathways to sustainability in the city: The case of San Juan, Puerto Rico. Ecol. Soc. 19. https://doi.org/10.5751/ES-06457-190302

Muñoz-Erickson TA, Lugo AE, Quintero B (2014) Emerging synthesis themes from the study of social-ecological systems of a tropical city. Ecol. Soc. 19:1-10. https://doi.org/10.5751/ES06385-190323

National Academies of Sciences, Engineering, and Medicine 2020. StrengtheningPost-Hurricane Supply Chain Resilience: Observations from Hurricanes Harvey,Irma, and Maria. Washington, DC: The National Academies Press.https://doi.org/10.17226/25490.

Nowak DJ, Greenfield EJ (2018) US urban forest statistics, values, and projections. J. For. 116: 164-177. https://doi.org/10.1093/jofore/fvx004 
Nowak DJ, Maco S, Binkley M (2018) i-Tree: Global tools to assess tree benefits and risks to improve forest management. Arboric. Consult 51: 10-13.

Olivero-Lora SS, Meléndez-Ackerman E, Santiago L, Santiago-Bartolomei RR, García-Montiel D (2019) Attitudes toward Residential Trees and Awareness of Tree Services and Disservices in a Tropical City. Sustainability 12:117. https://doi.org/10.3390/su12010117

Ordóñez C, Beckley T, Duinker PN, Sinclair AJ (2017) Public values associated with urban forests: Synthesis of findings and lessons learned from emerging methods and cross-cultural case studies. Urban For. Urban Green. 25:74-84. https://doi.org/10.1016/j.ufug.2017.05.002

Ostertag R, Silver WL, Lugo AE (2005) Factors affecting mortality and resistance to damage following hurricanes in a rehabilitated subtropical moist forest. Biotropica 37:16-24. https://doi.org/10.1111/j.1744-7429.2005.04052.x

Paull R, Duerte O (2011) Tropical Fruits. Second ed. CAB International, London, UK. https://doi.org/10.1016/B978-0-12-394807-6.00185-4

Ramos-González OM (2014) The green areas of San Juan, Puerto Rico. Ecol. Soc. 19:1-7. https://doi.org/10.5751/ES-06598-190321

Ramos-Scharrón CE, Arima E (2019) Hurricane María's Precipitation Signature in Puerto Rico: A Conceivable Presage of Rains to Come. Sci. Rep. 9:15612. https://doi.org/10.1038/s41598019-52198-2

Rodriguez-Diaz C (2018) Maria in Puerto Rico: natural disaster in a colonial archipelago. Am J Public Health 108:30-32.

Rojas-Sandoval J, Acevedo-Rodríguez P (2015) Naturalization and invasion of alien plants in Puerto Rico and the Virgin Islands. Biological Invasions 17(1):149-63.

Rojas-Sandoval J, Tremblay RL, Acevedo-Rodríguez P, Díaz-Soltero H (2017) Invasive plant species in the West Indies: geographical, ecological, and floristic insights. Ecology and Evolution 7(13):4522-33.

Roy S, Byrne J, Pickering C (2012) A systematic quantitative review of urban tree benefits, costs, and assessment methods across cities in different climatic zones. Urban forestry \& Urban Greening 1:351-63.

Steenberg JWN, Millward AA, Nowak DJ, Robinson PJ (2017) A conceptual framework of urban forest ecosystem vulnerability. Environ. Rev. 25:115-126. https://doi.org/10.1139/er2016-0022

Steenberg JWN, Millward AA, Nowak DJ, Robinson PJ, Smith SM (2019) A Social-Ecological Analysis of Urban Tree Vulnerability for publicly owned trees in a residential neighbourhood. Arboric. Urban For. 45:10-25. 
Subramanian R, Ellis A, Torres-Delgado E, Tanzer R, Malings C, Rivera F, Morales M, Baumgardner D, Presto A, Mayol-Bracero OL (2018) Air Quality in Puerto Rico in the Aftermath of Hurricane Maria: A Case Study on the Use of Lower Cost Air Quality Monitors. ACS Earth Sp. Chem. 2, 1179-1186. https://doi.org/10.1021/acsearthspacechem.8b00079

Tanner EVJ, Rodriguez-Sanchez F, Healey JR, Holdaway RJ, Bellingham PJ (2014) Long-term hurricane damage effects on tropical forest tree growth and mortality. Ecology 95:2974-2983. https://doi.org/10.1890/13-1801.1

Timilsina N, Staudhammer CL, Escobedo FJ, Lawrence A (2014) Tree biomass, wood waste yield, and carbon storage changes in an urban forest. Landscape and Urban Planning. 127:18-27.

Torres-Camacho KA, Meléndez-Ackerman EJ, Díaz E, Correa N, Vila-Ruiz C, Olivero-Lora S, Erazo A, Fontánez J, Santiago L, Seguinot, J (2017) Intrinsic and extrinsic drivers of yard vegetation in urban residential areas: implications for conservation planning. Urban Ecosyst. 20:403-413. https://doi.org/10.1007/s11252-016-0602-9

Tucker Lima JM, Staudhammer CL, Brandeis TJ, Escobedo FJ, Zipperer W (2013) Temporal dynamics of a subtropical urban forest in San Juan, Puerto Rico, 2001-2010. Landsc. Urban Plan. 120:96-106. https://doi.org/10.1016/j.landurbplan.2013.08.007

Uriarte M, Thompson J, Zimmerman JK (2019) Hurricane María tripled stem breaks and doubled tree mortality relative to other major storms. Nat. Commun. 10:1-7.

https://doi.org/10.1038/s41467-019-09319-2

U.S. Census Bureau (2019) https://www.census.gov/

U.S. Energy Information Administration (2018) EIA electricity sales data for Puerto Rico show rate of recovery since hurricanes - Today in Energy - U.S. Energy Information Administration https://www.eia.gov/todayinenergy/detail.php?id=36832 (accessed 12.6.19).

USDA-NRCS, 2019. The PLANTS database, National Plant Data Team. Greensboro, NC.

USDA-ARS-GRIN (2019) Germplasm Resources Information Network (GRIN-Taxonomy), Agricultural Research Service, National Plant Germplasm System. Beltsville, Maryland.

Van Beusekom AE, Álvarez-Berríos NL, Gould WA, Quiñones M, González G (2018) Hurricane Maria in the U.S. Caribbean: Disturbance forces, variation of effects, and implications for future storms. Remote Sens 10:1-14. https://doi.org/10.3390/rs10091386

Vila-Ruiz CP, Meléndez-Ackerman E, Santiago-Bartolomei R, Garcia-Montiel D, Lastra L, Figuerola CE, Fumero-Caban J (2014) Plant species richness and abundance in residential yards across a tropical watershed: Implications for urban sustainability. Ecol. Soc. 19, 1-11. https://doi.org/10.5751/ES-06164-190322 
Webster PJ, Holland GJ, Curry JA, Chang HR (2005) Changes in tropical cyclone number, duration, and intensity in a warming environment. Science 309:1844-1846.

Xi W (2015) Synergistic effects of tropical cyclones on forest ecosystems: a global synthesis. Journal of Forestry Research 26:1-21.

Yan P, Yang J (2018) Performances of urban tree species under disturbances in 120 cities in China. Forests 9:50. https://doi.org/10.3390/19020050

Yin J, Gentine P, Zhou S, Sullivan SC, Wang R, Zhang Y, Guo S (2018) Large increase in global storm runoff extremes driven by climate and anthropogenic changes. Nat. Commun. 9: 4389. https://doi.org/10.1038/s41467-018-06765-2

Zhao M, Escobedo FJ, Staudhammer C (2010) Spatial patterns of a subtropical, coastal urban forest: Implications for land tenure, hurricanes, and invasives. Urban For. Urban Green. 9: 205214. https://doi.org/10.1016/j.ufug.2010.01.008

Zimmerman JK, Waide RB, Lodge DJ, Taylor CM, Brokaw NVL, Everham EMI, Waide B, Lodge DJ, Taylor CM, Brokaw NVL (1994) Responses of Tree Species to Hurricane Winds in Subtropical Wet Forest in Puerto Rico: Implications for Tropical Tree Life Histories. J. Ecol. 82911. https://doi.org/10.2307/2261454

Zimmerman JK, Rojas-Sandoval J, Shiels AB (2021) Invasive Species in Puerto Rico: The View From El Yunque. Frontiers in Ecology and Evolution 9:58.

Zölch T, Maderspacher J, Wamsler C, Pauleit S (2016) Using green infrastructure for urban climate-proofing: An evaluation of heat mitigation measures at the micro-scale. Urban For. Urban Green. 20:305-316. https://doi.org/10.1016/j.ufug.2016.09.011 
Table 1. Description of the variables evaluated in pre- and post-hurricane surveys performed in San Juan residential yards.

\begin{tabular}{|c|c|}
\hline Variable & Description \\
\hline Origin & Native or non-native to Puerto Rico. Native distribution range according to Axelrod (2001). \\
\hline Life-form & $\begin{array}{l}\text { Tree, shrub, palm, large herb (including plantains and bananas). According to USDA-NRCS Plant } \\
\text { Database }\end{array}$ \\
\hline $\mathrm{DBH}$ & $\begin{array}{l}\text { Diameter at the breast heigh }(\mathrm{cm}) . \text { Five categories: } 1=2.5-7.6 \mathrm{~cm}, 2=7.7-15.2 \mathrm{~cm}, 3=15.3-30.5 \mathrm{~cm} \text {, } \\
4=30.6-45.7 \mathrm{~cm}, 5>45.7 \mathrm{~cm} .\end{array}$ \\
\hline Plant height & Distance in meters $(\mathrm{m})$ between the highest point of the main stem and the ground level. \\
\hline Canopy cover & Area in $\mathrm{m}^{2}$ covered by the vertical projection of the tree crowns. \\
\hline Leaf area & Area in $\mathrm{m}^{2}=$ leaf length $\times$ leaf width. \\
\hline Leaf area index & $\begin{array}{l}\text { LAI }=\text { leaf area }\left(\mathrm{m}^{2}\right) / \text { ground area }\left(\mathrm{m}^{2}\right) . \text { Defined as the one-sided green leaf area per unit ground surface } \\
\text { area. }\end{array}$ \\
\hline Leaf biomass & Product in kilograms $(\mathrm{kg})$ of leaf dry matter content and leaf area index. \\
\hline Crown condition & $\begin{array}{l}\text { Health condition of tree crowns that describes the amount of dieback within a tree's canopy. Estimated here } \\
\text { as } 1-\% \text { dieback. Seven categories: } 1=\text { dead, } 2=\text { dying, } 3=\text { critical, } 4=\text { poor, } 5=\text { fair, } 6=\text { good, } 7= \\
\text { excellent. }\end{array}$ \\
\hline Mortality & Binary $($ yes/no). $1=$ dead, $0=$ alive \\
\hline Bole damage & $\begin{array}{l}\text { Damage caused by hurricane winds in stems and trunks. Three categories: } 0=\text { no damage, } 1=\text { snapped } \\
\text { trunks, } 2=\text { uprooted stems. }\end{array}$ \\
\hline Recovery & Binary (yes/no). Evidence of new leaves production and/or new branches resprouting from stumps. \\
\hline Food provision value & Binary (yes/no). Species grown in gardens for food production According USDA-ARS-GRIN \\
\hline Ornamental value & Binary (yes/no). Species grown in gardens for its esthetic value. According USDA-ARS-GRIN \\
\hline
\end{tabular}


Table 2. Range values (lowest and highest), median values, and paired Sign test evaluating changes in vegetation structure and composition for 52 residential yards in San Juan. Asterisks $(*)$ indicates significant differences $(\mathrm{p}<0.05)$ between pre- and post-hurricane surveys.

\begin{tabular}{lllllll}
\hline \multirow{2}{*}{$\begin{array}{l}\text { Variables } \\
\text { Range }\end{array}$} & Median & Range & Median & $\boldsymbol{Z}$ test & p value \\
\hline Number of individuals & $1-42$ & 6.00 & $0-33$ & 5.00 & -5.66 & $\mathrm{p}<0.001^{*}$ \\
Number of species & $1-21$ & 3.50 & $0-19$ & 3.00 & -4.36 & $\mathrm{p}<0.001^{*}$ \\
Number of native species & $0-11$ & 0.00 & $0-9$ & 0.00 & -1.16 & $\mathrm{p}=0.250$ \\
DBH (cm) & $5.2-80.7$ & 10.63 & $0-80.7$ & 10.83 & 1.20 & $\mathrm{p}=0.230$ \\
Plant height $(\mathrm{m})$ & $1.8-19.00$ & 3.84 & $0-19.00$ & 3.87 & 0.70 & $\mathrm{p}=0.486$ \\
Canopy cover $\left(\mathrm{m}^{2}\right)$ & $1.3-546.9$ & 59.80 & $0-430.6$ & 42.85 & -5.75 & $\mathrm{p}<0.001^{*}$ \\
Leaf area $\left(\mathrm{m}^{2}\right)$ & $4.6-1,713.6$ & 219.45 & $0-1,441.9$ & 152.45 & -5.75 & $\mathrm{p}<0.001^{*}$ \\
Leaf biomass $(\mathrm{kg})$ & $0.3-140.0$ & 26.50 & $0-136.1$ & 20.55 & -5.75 & $\mathrm{p}<0.001^{*}$ \\
Leaf area index & $1.2-6.9$ & 3.18 & $0-5.9$ & 2.87 & -1.50 & $\mathrm{p}=0.134$ \\
Basal area $\left(\mathrm{m}^{2}\right)$ & $0-2.9$ & 0.00 & $0-2.5$ & 0.00 & -1.79 & $\mathrm{p}=0.062$ \\
\hline
\end{tabular}


Table 3. Estimates for ecosystem services provided by 52 residential yards in San Juan and the total percent loss estimated by comparing pre- and post-hurricane surveys using pooled yard data. Services are arranged from higher to lower percent loss.

\begin{tabular}{llllc}
\hline Ecosystem service & Pre-hurricane & Post-hurricane & Net loss & \% loss \\
\hline Food production (\# plants) & 227 & 132 & 95 & 41.9 \\
Avoided runoff (m²/yr) & 154.9 & 124.1 & 30.8 & 19.9 \\
Pollution removed (g/yr) & $25,082.6$ & $20,154.1$ & $4,928.5$ & 19.6 \\
Ornamental value (\# plants) & 262 & 221 & 41 & 15.6 \\
Cooling effects (Kwh/yr) & $6,081.1$ & $5,285.6$ & 795.5 & 13.1 \\
Oxygen produced (kg/yr) & $4,902.0$ & $4,348.1$ & 553.9 & 11.3 \\
Carbon sequestration (kg/yr) & $1,836.2$ & $1,630.1$ & 206.1 & 11.2 \\
Carbon storage (kg) & $29,914.8$ & $27,165.1$ & $2,749.7$ & 9.2 \\
\hline
\end{tabular}


Table 4. Variables used in binomial logistic regression models to evaluate mortality as a function of pre-hurricane values for vegetation structural variables and crown condition. Variables included in the best-fit model are indicated in bold letters. The plant species with $\mathrm{n}>10$ included in the analyses were: Annona muricata, Citrus aurantifolia, Codiaeum variegatum, Duranta spp., Dypsis lutescens, Ficus benjamina, Hibiscus rosa-sinensis, Mangifera indica, Psidium guajava and Ptychosperma macarthurii.

\begin{tabular}{|c|c|c|c|c|c|c|c|c|}
\hline \multirow[t]{2}{*}{ Variable } & \multirow[t]{2}{*}{ Estimates } & \multirow[t]{2}{*}{ SE } & \multirow[t]{2}{*}{ Wald $\chi^{2}$} & \multirow[t]{2}{*}{ df } & \multirow[t]{2}{*}{$\mathbf{P}$} & \multirow[t]{2}{*}{ Odds ratio } & \multicolumn{2}{|c|}{$95 \% \mathrm{CI}$} \\
\hline & & & & & & & lower & upper \\
\hline Intercept & -1.985 & 1.197 & 2.751 & 1 & 0.097 & 0.137 & & \\
\hline DBH (cm) & -0.121 & 0.058 & 4.304 & 1 & 0.038 & 0.886 & 0.79 & 0.993 \\
\hline Plant height (m) & 0.322 & 0.196 & 2.715 & 1 & 0.099 & 1.38 & 0.941 & 2.025 \\
\hline Crown condition "bad" & 0.507 & 0.814 & 0.388 & 1 & 0.533 & 1.661 & 0.337 & 8.195 \\
\hline Crown condition "fair" & -0.629 & 0.463 & 1.849 & 1 & 0.174 & 0.533 & 0.215 & 1.32 \\
\hline
\end{tabular}


Urban Ecosystems

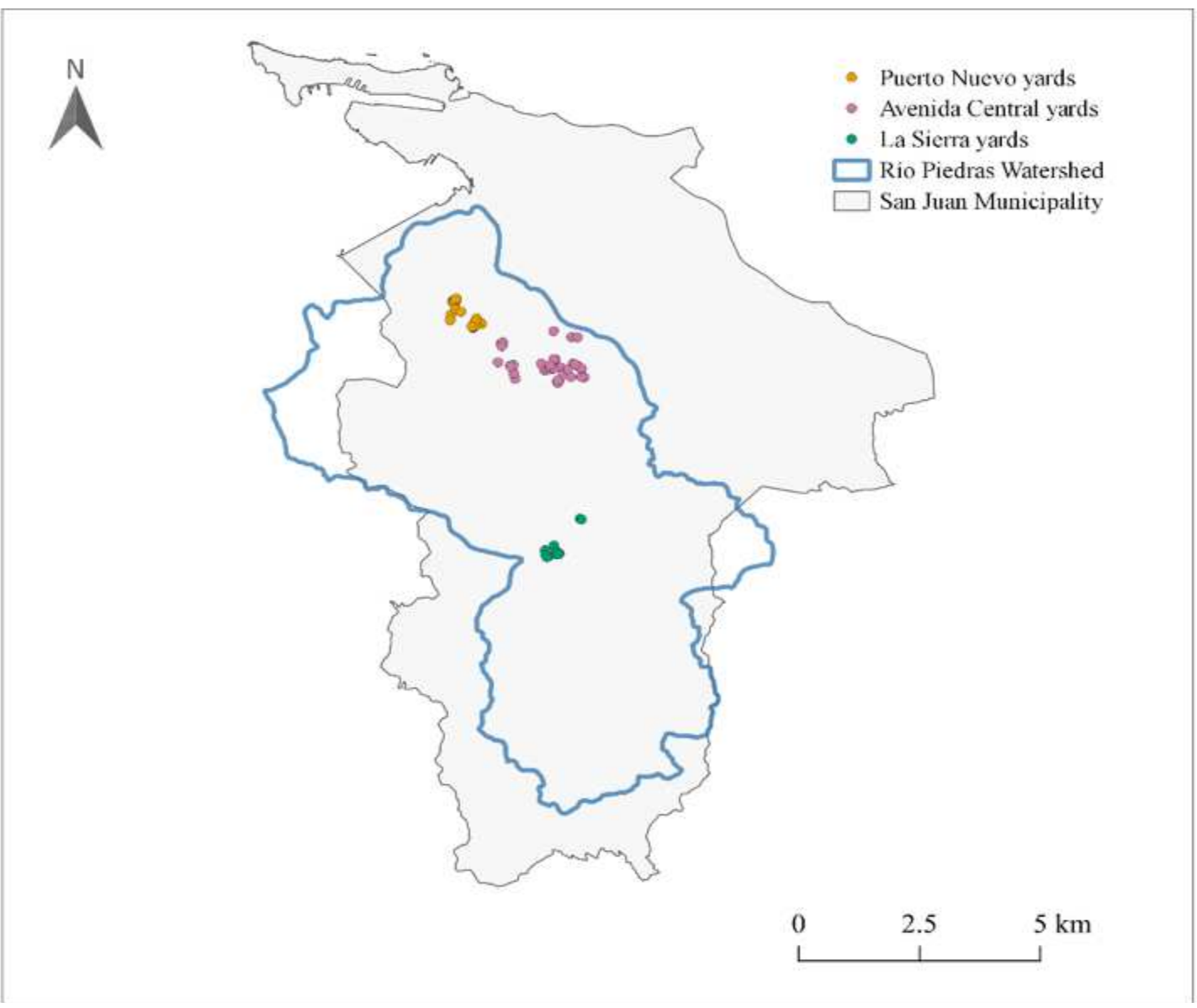

Figure 1. Location within the Río Piedras Watershed and the San Juan Municipality of the yards used for pre- and post-hurricane surveys. 


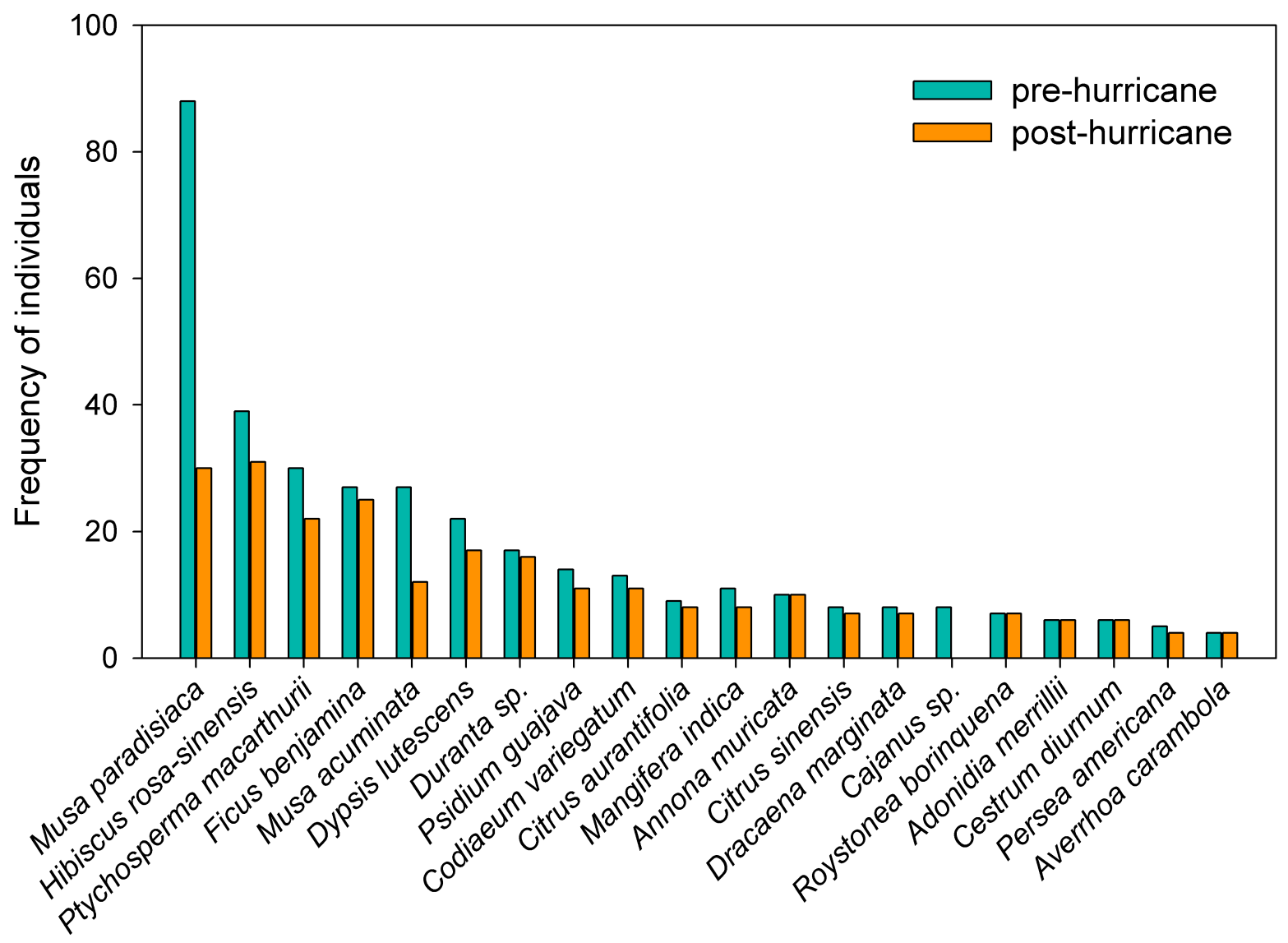

Figure 2. Frequency of 20 most common plant species found in San Juan yards for the pre-and post-hurricane surveys. 


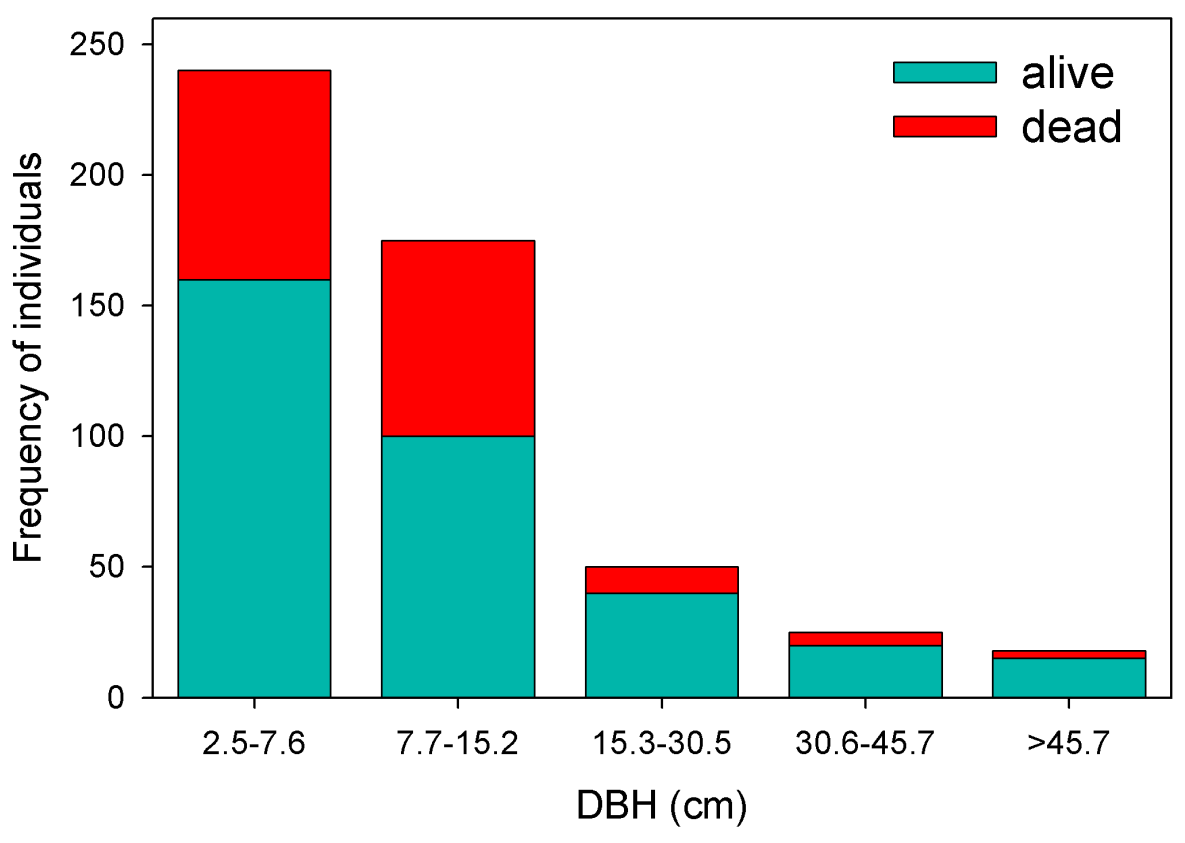

Figure 3. Frequency of dead and alive individual plants in each of the five DBH size-classes comparing pre- and post-hurricane surveys. 


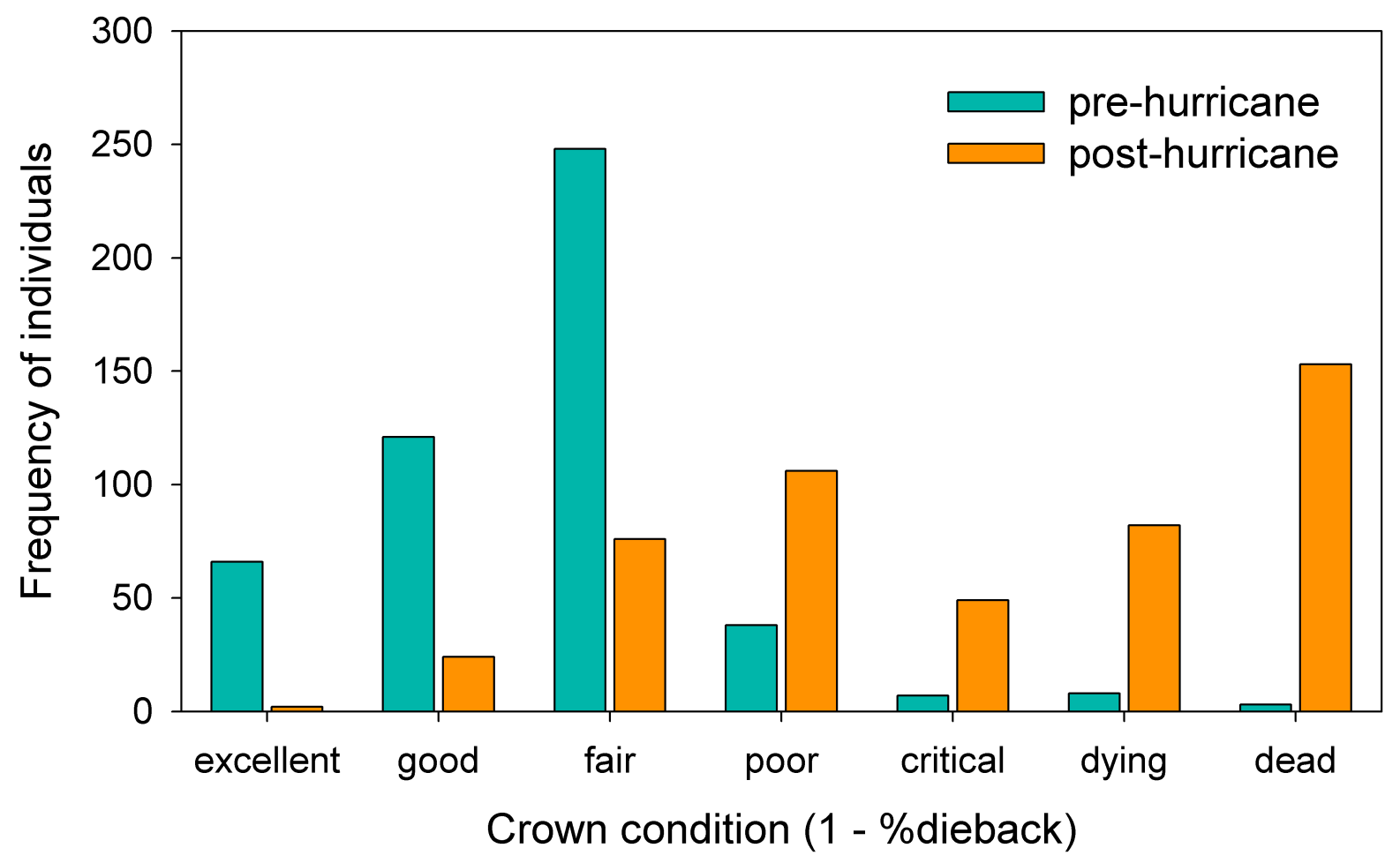

Figure 4. Crow condition for individual plants comparing pre- and post-hurricane surveys. 
Urban Ecosystems

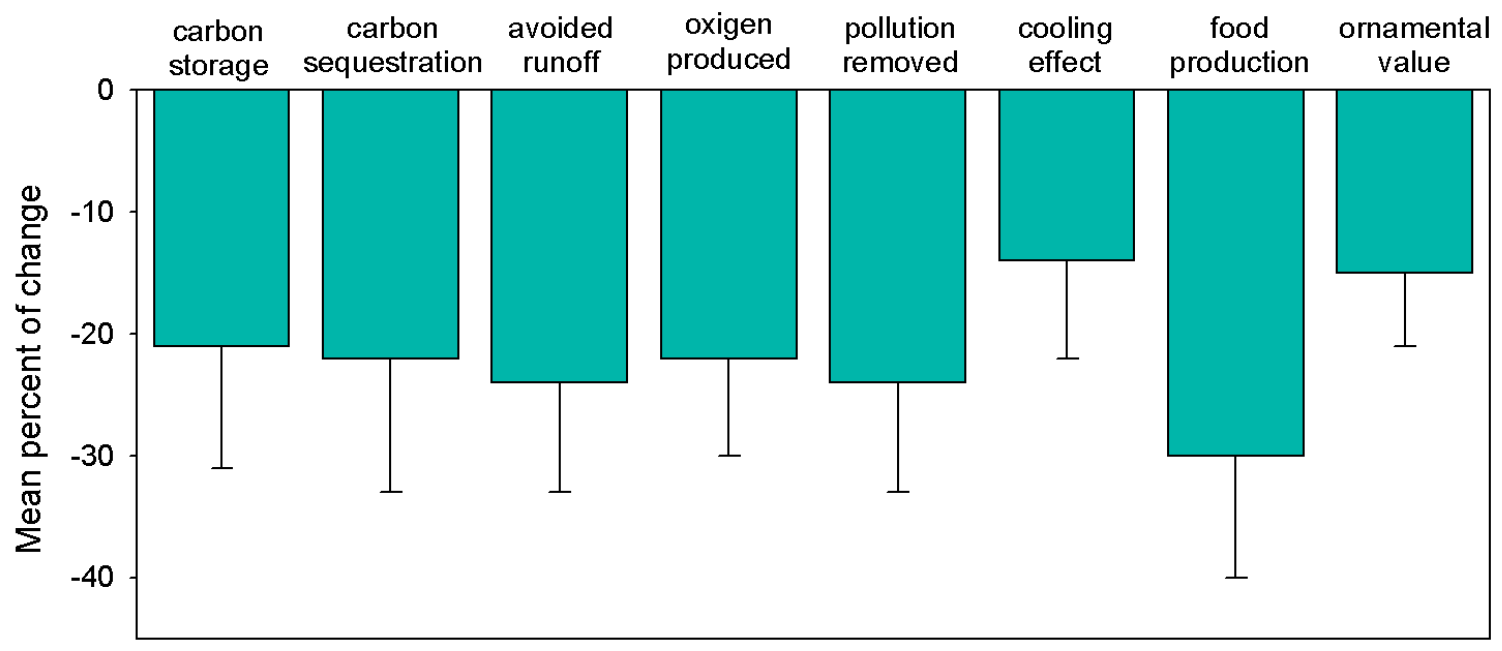

Figure 5. Mean percent of losses in ecosystem services provided by 52 yards in San Juan. 

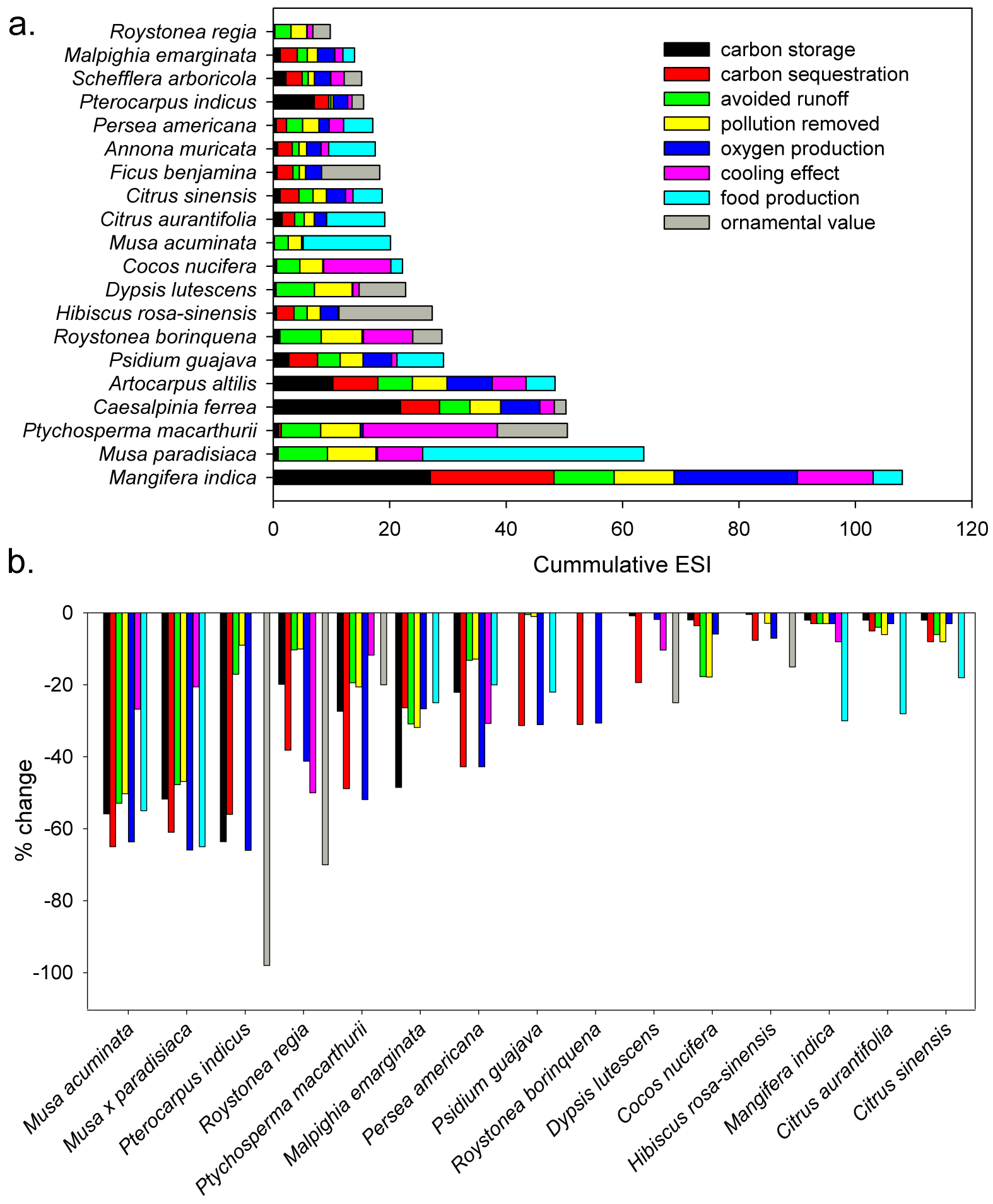

Figure 6a. Distribution of ecosystem services by species. a) Comparison of the top 20 species with the highest relative contribution to multiple ecosystem services (ESI= ecosystem service index) before the hurricane events. b) Percent of losses of ecosystem services for the top contributors. Species are ranked according to the cumulative $\%$ of losses. Only species with undergoing losses were included in this figure. 


\section{Supplementary Files}

This is a list of supplementary files associated with this preprint. Click to download.

- Supportinglnformation.pdf 